\title{
SISTEM INFORMASI PENDAFTARAN DAN CAREER TEST STUDY KASUS PADA CV. XYZ
}

\author{
Yogi Eka Sakti $^{1)}$, Hendro Poerbo Prasetiya, ST, M.MT, OCA. ${ }^{2)}$ \\ 1) Sistem Informasi Universitas Ma Chung ${ }^{2}$ ) Sistem Informasi Universitas Ma Chung \\ E-mail: 321310006@student.machung.ac.id ${ }^{1)}$ hendro.poerbo@machung.ac.id ${ }^{2}$
}

\begin{abstract}
Abstraksi
Dalam menjalankan proses bisnis pendaftaran dan Career Test seringkali CV. XYZ mengalami kendala yang menyebabkan proses pendaftaran dan Career Test membutuhkan waktu yang lama. Hal ini disebabkan karena seluruh proses baik proses pendaftaran maupun Career Test dilakukan secara manual. Oleh karena itu, dibuatlah sistem informasi pendaftaran dan Career Test yang dapat dilakukan secara online.

Metodologi yang digunakan dalam pengembangan sistem adalah metoda three major phases. Hasil dari pengembangan sistem yang telah dirancang dapat menampilkan informasi umum CV. XYZ, daftar universitas dan profiling kampus, halaman register yang digunakan untuk membuat account di CV. XYZ, halaman career test, dan halaman untuk mendaftar di universitas yang diinginkan. Selain pengembangan sistem untuk student, terdapat pengembangan sistem untuk admin.

Hasil dari pengembangan sistem yang telah dirancang untuk admin dapat menampilkan form login untuk admin, dashboard laporan yang berisi informasi mengenai jumlah pendaftaran per tahun dan laporan siswa yang mendaftaran ke universitas dalam kurun waktu satu tahun, admin juga dapat melakukan update pada data negara, universitas, jurusan, soal career test, security option dan detail universitas. Dengan adanya sistem ini, siswa dapat terbantu untuk mendapatkan informasi mengenai universitas yang akan dituju dan lebih mudah dalam melengkapi dokumen syarat pendaftaran. Selain itu, dengan adanya sistem ini, proses career test lebih efektif dan efisien baik bagi perusahaan maupun bagi siswa dan siswi. Sedangkan bagi admin, sistem ini dapat memudahkan admin dalam melakukan rekap student dan mengumpulkan dokumen pendaftaran.
\end{abstract}

\section{Kata-Kata Kunci:}

three major phases, career test, pendaftaran, universitas, student, admin.

\section{Abstract}

In running the business process on registration and career test, CV. XYZ is often has obtacles that cause the registration process and career test takes a long time. This is because the whole process of both the registration process and career test done manually.

Therefore, information system for registration and career test are created so registration and career test can be done online. The methodology used in system development is the three major phrases method. The results of the system development that has been designed to display general information of $C V . X Y Z$, university list and profiling, register page used to create account in $C V$. XYZ, career test page, and a page to enroll in the desired university. In addition to system development for students, there is a system development for admin.

The result of system development that has been designed for admin can display login form for admin, dashboard report which contains information about the number of registration per year and student report that enroll to university within one year, admin can also update on state data, university, majors, career test questions, security options and university details. With this system, students can be helpful to get information about the university to be addressed and easier in completing the registration requirements documents. In addition, with this system, the career test process is more effective and efficient both for the company and for students. As for admin, this system can facilitate admin in make student report and collect registration documents.

\section{Key Words:}

three major phases, career test, registration, university, student, admin 


\section{Pendahuluan}

CV. XYZ merupakan sebuah perusahaan yang bergerak dibidang jasa konsultan mengenai studi ke luar negeri. CV. XYZ juga memberikan jasa career test untuk siswa dan siswi yang ingin mengetahui bakat dan minatnya. Selain kedua layanan tersebut $\mathrm{CV}$. XYZ juga membantu para siswa dan siswi dalam pengurusan dan legalisir dokumendokumen yang dibutuhkan untuk melengkapi persyaratan yang dibutuhkan untuk dapat masuk ke universitas luar negeri yang diinginkan.

Dalam menjalankan proses bisnis pendaftaran dan Career Test seringkali terdapat kendala yang menyebabkan proses pendaftaran dan Career Test memakan waktu yang lama. Kendala yang terjadi dalam proses pendaftaran dan Career Test diantaranya adalah proses pendaftaran yang dilakukan masih berjalan secara manual.

Pihak CV. XYZ juga masih menyimpan data siswa dan siswi secara manual dan belum menggunakan database. CV. XYZ melakukan rekap data siswa yang mendaftar setiap bulannya dengan mengarsip data tersebut secara manual, sehingga pihak CV. XYZ harus menyediakan tempat extra yang digunakan untuk tempat

sistemnya. Sistem dibangun menggunakan Bahasa pemrograman PHP, karena sistem ini berbasis web, dengan MySQL sebagai databasenya. Penelitian ini diharapkan dapat mempermudah dan mempercepat proses pendaftaran and career test pada CV. XYZ.

\section{Tinjauan Pustaka}

Penelitian yang dilakukan oleh Irwin Nugroho, Mahasiswa Teknik Informatika Universitas Negeri Yogyakarta bertujuan untuk menghasilkan perangkat lunak Sistem Informasi penerimaan siswa baru berbasis web dengan menggunakan PHP dan SQL. Jenis penelitian yang digunakna adalah research and development, sedangkan metoda pengembangan perangkat lunak menggunakan waterfall model. Hasil dari penelitian ini menunjukkan bahwa sistem informasi penerimaan siswa baru berbasis web mampu mengelola pelaksanaan penerimaan siswa baru.

Selain Irwin Nugroho, terdapat M. Irfandi, Desi Amirullan dan Mansur yang merupakan bahasiswa Politeknik Negeri Bengkalis yang juga melakukan penelitian yang mambahas mengenai sistem informasi penerimaan siswa baru yang mampu mempermudah kinerja panitia penyimpanan data siswa tersebut. Selain itu data rekapan yang disimpan secara manual akan memperlambat proses dalam melihat laporan data historis seperti melihat jumlah siswa yang mendaftar, jumlah siswa yang berangkat dan laporan lainnya secara periodik.

Oleh karena itu, CV. XYZ memerlukan adanya sistem informasi pendaftaran dan Career Test yang dapat dilakukan secara online. Adanya sistem informasi pendaftaran dan Career Test ini akan membuat proses pengisian form pendaftaran dan pengisian Career Test dapat dilakukan di rumah secara cepat, selain itu para siswa dan siswi juga dapat melakukan upload file yang dibutuhkan untuk melengkapi syarat pendaftaran. Selain itu, para siswa juga dapat mengetahui rekomendasi apa yang diberikan secara cepat setelah proses Career Test dijalankan, dan pihak CV. XYZ dapat melihat laporan historis dengan cepat dengan adanya database yang terintegrasi. Dengan adanya sistem informasi ini diharapkan agar pembangunan sistem dapat membantu CV. XYZ dalam mempercepat proses pendaftaran dan Career Test. Adapun metoda yang digunakan dalam penelitian ini adalah metoda three major phases untuk perancangan dan pembangunan

penerimaan siswa baru dalam melakukan input dan mengolah data calon siswa baru di Madrasah Aliyah Negeri Bengkalis. Sistem informasi ini menggunakan bahasa pemrograman Java dan database Oracle XE.

Adisti Frediyana Sukadi, mahasiswi program studi sistem informasi Sekolah Tinggi Ilmu Tarbiyah Muhammadiyah Pacitan melakukan penelitian dengan membahas mengenai analisis sistem informasi yang mampu mengelola dan mengolah data secara efektif dan efisien sehingga terjadi komputerisasi data. Hasil dari pembahasan yang telah dilakukan adalah bahwa sistem pendaftaran mahasiswa baru di Sekolah Tinggi Ilmu Tarbiyah Muhammadiyah Pacitan membutuhkan sebuah perancangan sistem informasi pendaftaran mahasiswa baru agar mempermudah kinerja admin dalam melakukan pengolahan data serta pengambilan keputusan.

Berbeda dengan beberapa penelitian yang telah dilakukan, penelitian ini tidak hanya membahas mengenai pendaftaran siswa, namun juga membahas mengenai proses career test yang dilakukan secara online pada CV. XYZ.

Penelitian ini menggunakan bahasa pemrograman PHP dengan database MySQL. 
Penelitian ini juga tidak hanya menganalisis sistem, namun juga merancang sebuah sistem informasi pendaftaran dan career test yang bermanfaat dalam membantu proses bisnis pendaftaran dan career test secara online pada CV. XYZ.

Sistem informasi merupakan gabungan dari kata sistem dan informasi. Suatu sistem terdiri dari sejumlah komponen yang saling berinteraksi atau dengan kata lain saling bekerjasama membentuk satu kesatuan untuk mencapai tujuan tertentu. Sedangkan informasi adalah data yang diolah menjadi bentuk yang lebih berguna dan lebih berarti bagi penerimanya[1]. Sehingga dapat disimpulkan bahwa konsep dasar sistem informasi adalah suatu sistem di dalam suatu organisasi yang mempertemukan kebutuhan pengelolaan transaksi harian, mendukung operasi, bersifat manajerial, dan kegiatan strategi keputusan, dan persiapan prososal. Pada tahap desain, kegiatan yang dilakukan adalah mendesain data inputan yang diperlukan, desain input dan output dan pengaturan data. Sedangkan pada tahap implementasi dibagi menjadi dua kegiatan yaitu implementasi dan evaluasi.

Hypertext Preprocessor adalah bahasa pemrograman web server-side yang bersifat open source. PHP merupakan script yang terintegrasi dengan HTML dan berada pada server (server side HTML embedded scripting). Selain itu, PHP adalah script yang digunakan untuk membuat laman website yang dinamis. Dinamis yang dimaksudkan berarti halaman yang akan ditampilkan dibuat saat laman itu diminta atau diakses oleh client. Mekanisme ini menyebabkan informasi yang diterima client selalu yang terbaru atau up to date. Semua script PHP dieksekusi pada server dimana script itu
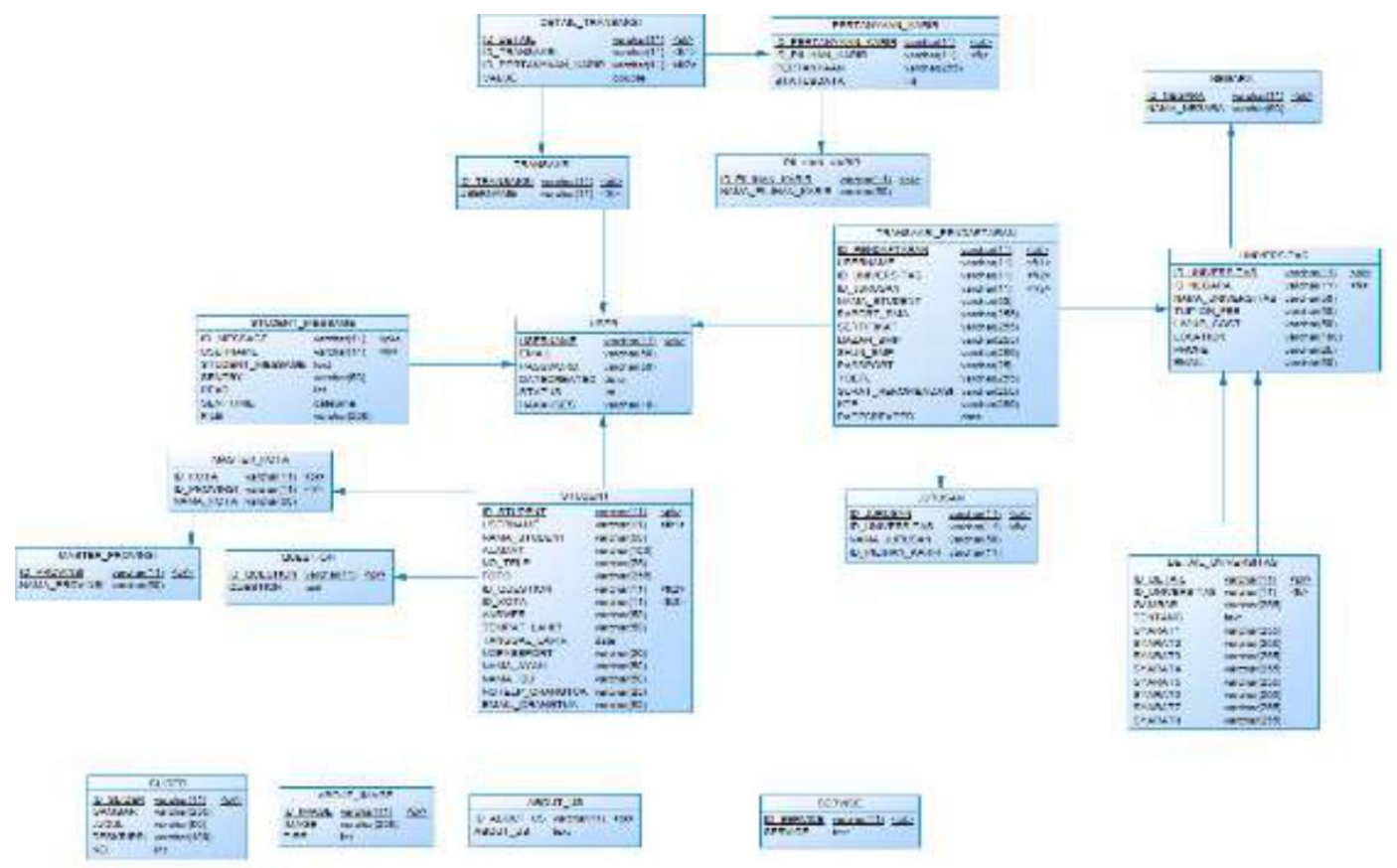

\section{Gambar 2 Entity Relationship Diagram}

dari suatu organisasi dan menyediakan pihak luar tertentu dengan laporan-laporan yang dibutuhkan. Three Major Phases merupakan bagian dari SDLC yaitu 3 tahapan utama yang terdapat pada setiap metodologi. Bertujuan untuk menganalisis penelitian atau proyek kemudian mendesain sistem yang merupakan proyek tersebut, yakni solusi dari analisis yang telah

dilakukan, kemudian membangun dan menerapkan sistem tersebut [2]. Pada tahap analisis, kegiatan yang dilakukan adalah mengumpulkan data, alur data dan analisis dijalankan [3].

Skala yang digunakan dalam A Quick Measure of Motivation Achievement merupakan alat ujian yang mengukur motivasi pencapaian setiap individu dalam kewirausahaan khususnya pada bidang pekerjaan. Menurut Dr. Nor Ba'yah Abdul Kadir dalam McClelland, terdapat 3 motif motivasi pencapaian individu yaitu power, affiliation, dan achievement. Motif power melibatkan emosi dan efek pada perilaku orang lain, motif affiliation melibatkan stabilitas, dan pemulihan hubungan baik dengan orang lain, 
sedangkan motif achievement melibatkan persaingan dalam mengejar keunggulan, atau memberikan suatu kontribusi yang unik. Hal ini menjelaskan bahwa dasar dari tes ini adalah untuk menguji motivasi individu dalam hubungan interpersonal dalam suatu organisasi maupun pekerjaan.

\section{Metoda Penelitian}

Metoda yang digunakan dalam penelitian ini adalah metoda three major phases, oleh karena itu tahapan penelitiannya adalah sebagai berikut.

\section{Analisis}

Pada tahap analisis terdapat beberapa aktivitas mengetahui sistem yang sedang berjalan pada CV. XYZ, maka dibuatlah usulan penggunaan sistem informasi pendaftaran \& career test pada CV. XYZ. Sesuai dengan workflow sistem yang diusulkan maka aktor-aktor yang terlibat dalam sistem adalah pemilik, admin, dan siswa.

d. Proposal Preparation

Kegiatan yang dilakukan pada proposal preparation adalah melakukan pengajuan seminar proposal. Dalam seminar proposal tersebut telah dibahas mengenai pendahuluan, landasan teori, penelitian terdahulu, analisis dan perancangan sistem informasi pendaftaran \& Career test yang

\section{WORKFLOW Sistem yang Diusulkan}

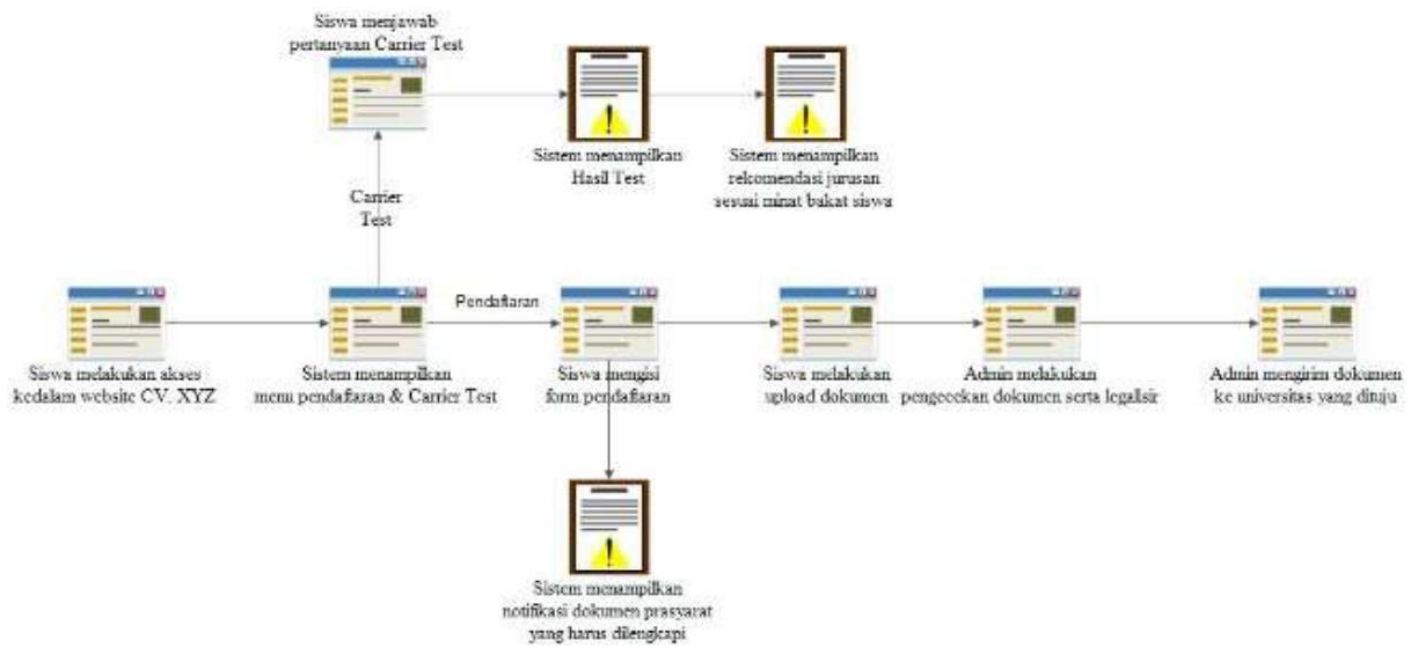

Gambar 1 Workflow Sistem yang Diusulkan

yang diperoleh, yaitu sebagai berikut.

\section{a. Data Gathering}

b. Kegiatan yang dilakukan pada tahap data gathering adalah melakukan pengumpulan data dengan cara melakukan observasi ke kantor CV. XYZ serta melakukan wawancara kepada Ibu Adelia selaku admin dari CV. XYZ. Hasil wawancara tersebut dapat dilihat pada bagian lampiran pada penelitian ini.

c. Data Flow and Decision Analysis

Kegiatan yang dilakukan pada tahap data flow and decision analysis adalah membuat alur proses bisnis yang sedang berjalan pada CV. XYZ berdasarkan observasi dan wawancara yang telah dilakukan pada tahap pengumpulan data yang digambarkan pada bentuk workflow yang berjalan. Setelah dibangun.

\section{Desain}

Tahap desain merupakan kegiatan merancang dan mendesain sistem yang akan dibangun serta memiliki manfaat untuk menjawab hasil analisis yang telah dilakukan pada tahap sebelumnya. Desain yang dilakukan diantaranya adalah mendesain data input dan output yang diperlukan. Berdasarkan analisis alur data yang telah dilakukan maka peneliti melakukan desain data inputan yang dibutuhkan, desain ERD, serta desain tampilan input dan output dari sistem yang dibangun. Berdasarkan ERD yang telah dibuat, kamus data yang nantinya akan digunakan untuk menyimpan data yang diperlukan adalah sebagai berikut. 
a. User merupakan tabel yang menyimpan $I D$ dan nama user siapa saja yang masuk kedalam sistem

b. Tabel About Image merupakan tabel yang menyimpan data gambar pada halaman about us di website.

c. Tabel about us merupakan tabel yang menyimpan data informasi mengenai halaman about us di

website 3. Implementasi

Tahap implementasi merupakan tahap dimana kegiatan yang dilakukan dibagi menjadi dua yaitu implementasi dan evaluasi.

Implementasi dilakukan dengan mengimplementasikan rancangan sistem yang telah dianalisis menjadi sebuah aplikasi pendaftaran \& Career Test berbasis web, sedangkan proses evaluasi akan dilakukan setelah adanya kritik dan saran dari pihak $\mathrm{CV}$. $\mathrm{XYZ}$ dan dosen penguji.

\section{Hasil dan Pembahasan}

Pada saat pertama kali sistem dibuka, sistem akan menampilkan halaman home. Pada halaman home terdapat logo dan nama perusahaan, informasi nomor telepon dan alamat email admin di header, terdapat pula sub menu yang dapat diakses oleh siswa yaitu sub menu daftar universitas, about us, our service, dan sub menu login. Halaman university list merupakan daftar universitas yang melakukan kerja sama dengan CV. XYZ. Menu University List dapat diakses oleh siswa untuk mengetahui profil dari kampus yang ingin dituju. Di dalamnya terdapat informasi mengenai profiling kampus, lokasi, dan persyaratan yang dibutuhkan untuk mendaftar ke kampus tersebut. Halaman about us memuat informasi mengenai Profil dari CV. XYZ sendiri, selain profil terdapat pula informasi mengenai penghargaan dan prestasi yang pernah diterima oleh CV. XYZ, Contact dari admin CV. XYZ yang dapat dihubungi seperti nomor telepon dan E-mail. Halaman our service memuat informasi mengenai layanan apa saja yang diberikan oleh CV. XYZ kepada siswa dan siswi yang ingin melanjutkan study keluar negeri dengan bantuan dari CV. XYZ. Sedangkan halaman login memuat form yang harus diisi oleh user untuk dapat mengakses sistem.

Halaman login adalah halaman untuk user yang telah memiliki account, sedangkan user yang belum memiliki account dapat memilih menu register. Halaman register merupakan form yang harus diisi oleh siswa agar nantinya siswa tersebut dapat masuk kedalam sistem. Form Register mengharuskan siswa untuk mengisi User Name, E-Mail, Security Option, dan Password untuk dapat membuat sebuah akun baru. Apabila siswa lupa pada passwordnya di halaman login siswa dapat memilih menu forgot password. Pada form forgot password ini siswa harus mengisikan usernamenya untuk dapat melakukan recovery terhadap password. Setelah username diisi dan siswa menekan tombol recovermaka akan muncul security option. Pada form security option, siswa harus menjawab security option yang sudah disediakan oleh sistem dan telah diisi oleh user saat user tersebut melakukan proses register. Setelah berhasil menjawab maka sistem akan menampilkan form berisi penggantian password yang baru. Pada Form penggantian password, siswa diharuskan untuk mengisi password yang baru kemudian memilih Reset My Password untuk mengganti password yang lama dengan yang baru. Setelah itu akan muncul notifikasi bahwa password telah berhasil diganti dan siswa dapat melakukan login dengan password yang baru.

Pada saat login terdapat menu data diri siswa. Pada menu data diri siswa, terdapat sebuah form yang berisi identitas yang harus diisi oleh siswa meliputi Foto, Nama. E-mail, No Telepon, Alamat, Provinsi, Kota, Tempat lahir, 


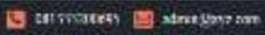

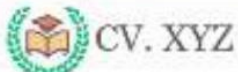

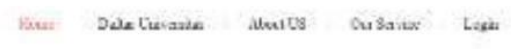

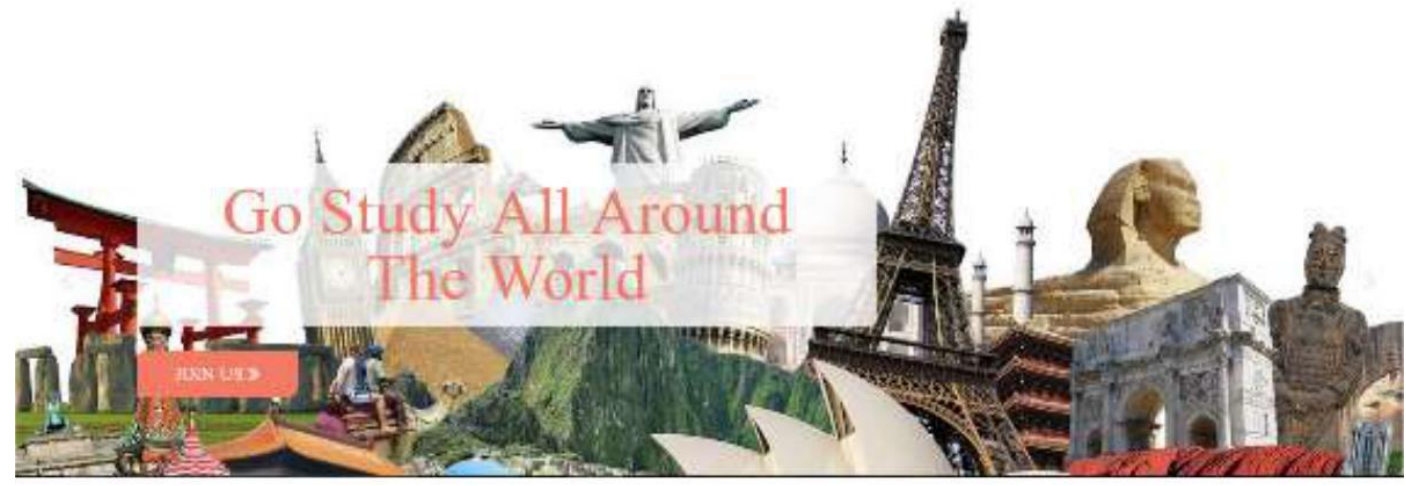

Gambar 3 Halaman Home

Tanggal lahir, nomor passport, Nama orangtua, nomor telepon orang tua serta alamat E-mail orang tua siswa.

Menu Career Test merupakan tempat bagi siswa untuk melakukan Career Test. Siswa harus menekan button Start test untuk memulai Career Test. Gambar 4 adalah halaman career test yang berisi soal-soal yang harus dikerjakan untuk memperoleh perkiraan bakat minat siswa. Terdapat 40 pertanyaan yang terdiri dari 8 kategori Career yang harus dijawab oleh siswa. Terdapat instruksi pengerjaan dan siswa dapat menjawab soal dengan memilih jawaban yang tersedia dibawah pertanyaan. Setelah selesai siswa dapat mengetahui hasilnya di menu Dashboard. Setiap siswa hanya dapat melakukan

\section{1 kali Career test.}

Setelah siswa melakukan career test maka akan muncul halaman dashboard yang menampilkan hasil dari career test yang telah dilakukan. Terdapat 8 kategori yang nantinya dapat dipilih sesuai dengan minat dari siswa tersebut. Apabila menu kategori ini dipilih maka akan memunculkan menu daftar jurusan yang berhubungan dengan kategori Career yang diminati oleh siswa. Pada daftar jurusan terdapat pilihan jurusan yang tersedia sesuai dengan kategori yang dipilih, pilihan sekolah, negara estimasi biaya sekolah, estimasi biaya hidup, serta link untuk melihat profil sekolah dan link untuk melakukan pendaftaran.

Pada form pendaftaran siswa hanya tinggal melakukan upload dokumen persyaratan yang dibutuhkan untuk dapat masuk kedalam universitas yang diinginkan setelah berhasil melakukan upload dokumen, siswa dapat memilih apply untuk menyelesaikan proses pendaftaran. Data pendaftaran akan disimpan kedalam database oleh sistem.

Halaman login adalah halaman untuk user yang telah memiliki account, sedangkan user yang belum memiliki account dapat memilih menu register. Halaman register merupakan form yang harus diisi oleh siswa agar nantinya siswa tersebut dapat masuk kedalam sistem. Form Register mengharuskan siswa untuk mengisi User Name, EMail, Security Option, dan Password untuk dapat membuat sebuah akun baru. Apabila siswa lupa pada passwordnya di halaman login siswa dapat memilih menu forgot password. Pada form forgot password ini siswa harus mengisikan usernamenya untuk dapat melakukan recovery terhadap password. Setelah username diisi dan siswa menekan tombol recovermaka akan muncul security option. Pada form security option, siswa harus menjawab security option yang sudah disediakan oleh sistem dan telah diisi oleh user saat user tersebut melakukan proses register. Setelah berhasil menjawab maka sistem akan menampilkan form berisi penggantian password yang baru. Pada Form penggantian password, siswa diharuskan untuk mengisi password yang baru kemudian memilih Reset My Password untuk mengganti password yang lama dengan yang baru. Setelah itu akan muncul notifikasi bahwa password telah berhasil diganti dan siswa dapat melakukan login dengan password yang baru. 


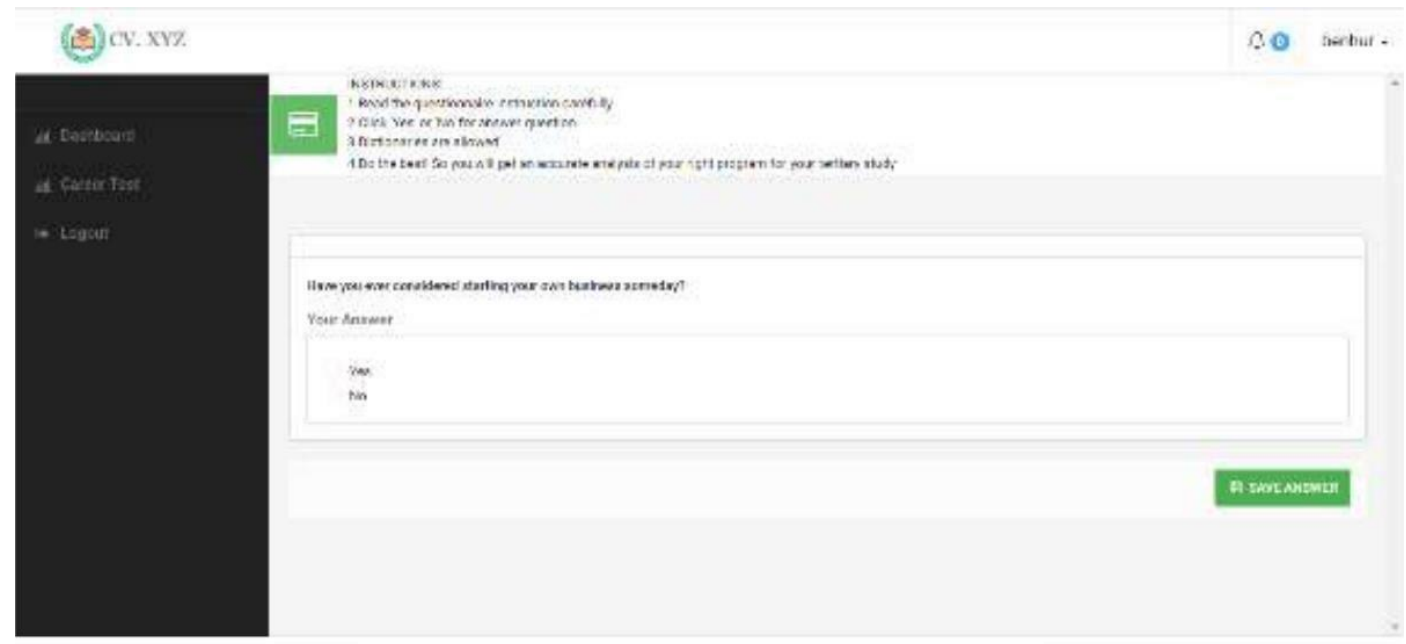

Gambar 4 Halaman Career Test

Pada saat login terdapat menu data diri siswa. Pada menu data diri siswa, terdapat sebuah form yang berisi identitas yang harus diisi oleh siswa meliputi Foto, Nama. E-mail, No Telepon, Alamat, Provinsi, Kota, Tempat lahir, Tanggal lahir, nomor passport, Nama orangtua, nomor telepon orang tua serta alamat E-mail orang tua siswa.

Menu Career Test merupakan tempat bagi siswa untuk melakukan Career Test. Siswa harus menekan button Start test untuk memulai Career Test. Gambar 4 adalah halaman career test yang berisi soal-soal yang harus dikerjakan untuk memperoleh perkiraan bakat minat siswa. Terdapat 40 pertanyaan yang terdiri dari 8 kategori Career yang harus dijawab oleh siswa. Terdapat instruksi pengerjaan dan siswa dapat menjawab soal dengan memilih jawaban yang tersedia dibawah pertanyaan. Setelah selesai siswa dapat mengetahui hasilnya di menu Dashboard. Setiap siswa hanya dapat melakukan

\section{1 kali Career test.}

Setelah siswa melakukan career test maka akan muncul halaman dashboard yang menampilkan hasil dari career test yang telah dilakukan. Terdapat 8 kategori yang nantinya dapat dipilih sesuai dengan minat dari siswa tersebut. Apabila menu kategori ini dipilih maka akan memunculkan menu daftar jurusan yang berhubungan dengan kategori Career yang diminati oleh siswa. Pada daftar jurusan terdapat pilihan jurusan yang tersedia sesuai dengan kategori yang dipilih, pilihan sekolah, negara estimasi biaya sekolah, estimasi biaya hidup, serta link untuk melihat profil sekolah dan link untuk melakukan pendaftaran.

Pada form pendaftaran siswa hanya tinggal melakukan upload dokumen persyaratan yang dibutuhkan untuk dapat masuk kedalam universitas yang diinginkan setelah berhasil melakukan upload dokumen, siswa dapat memilih apply untuk menyelesaikan proses pendaftaran. Data pendaftaran akan disimpan kedalam database oleh sistem.

Selain halaman yang ditampilkan untuk user, terdapat halaman yang hanya dapat dilihat oleh admin. Agar admin dapat masuk ke halaman admin, maka admin harus melakukan login terlebih dahulu. Terdapat form login yang harus diisi oleh admin CV. XYZ untuk dapat masuk ke dalam sistem. Form ini berisi username dan password yang harus diisikan agar admin dapat masuk ke dalam sistem untuk melakukan pengolahan data.

Setelah admin melakukan login, maka akan muncul halaman home admin. Pada halaman home admin, terdapat dashboard laporan yang berisi informasi mengenai jumlah pendaftaran user website per tahun, serta laporan siswa yang mendaftar ke universitas dalam kurun waktu satu tahun. Selain itu, terdapat menu student list, admin CV. XYZ dapat melihat seluruh informasi mengenai siswa dan siswi siapa sajakah yang telah melakukan register ke dalam sistem.

Dengan menggunakan sistem ini, admin dapat melakukan kegiatan manipulasi data seperti melakukan update, edit, dan delete terhadap data negara, universitas, jurusan, soal career test, security option, detail universitas, 


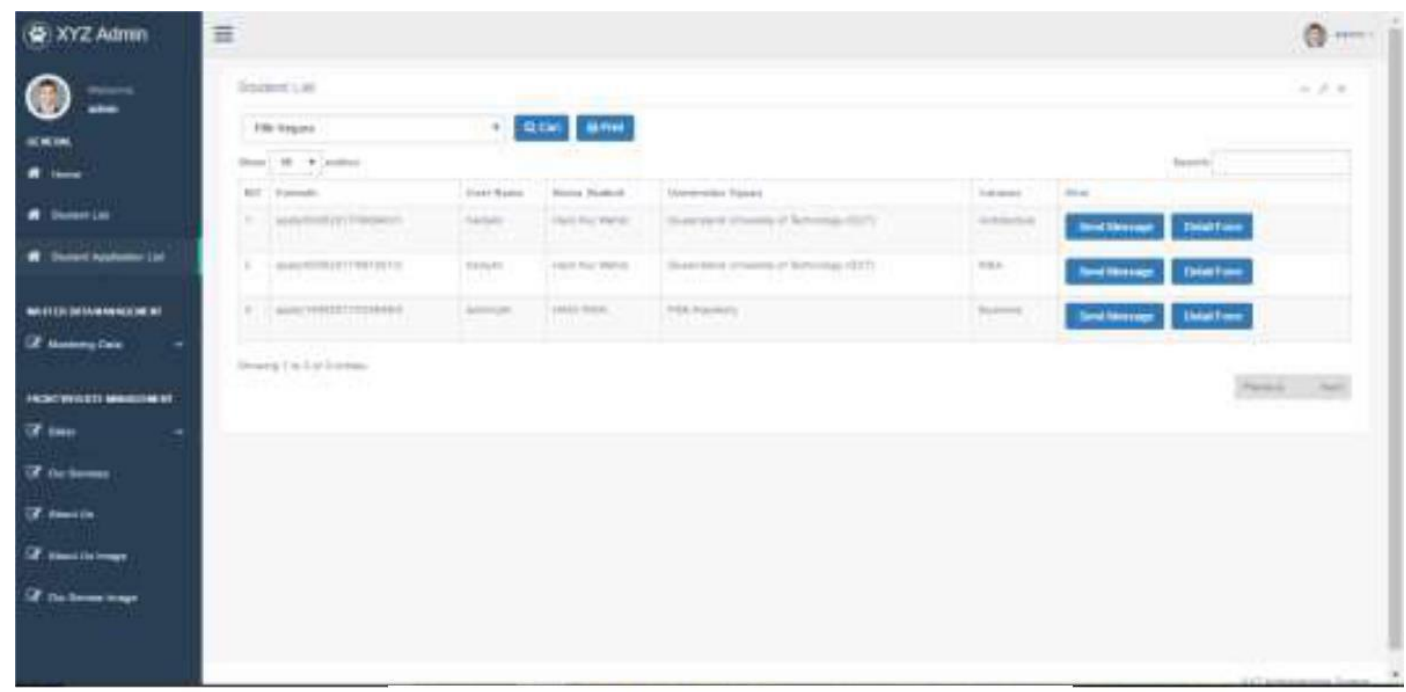

Gambar 5 Form Application List

kota, serta provinsi. Kegiatan pengolahan data sistem akan dilakukan pada form mastering data. Dalam melakukan manipulasi data, admin dapat melakukannya melalui menu front website management untuk melakukan manipulasi data pada bagian home website. Admin dapat mengganti slider, gambar, dan artikel yang ada pada CV. XYZ.

Dengan menggunakan sistem ini, admin dapat melihat laporan siswa yang telah melakukan career test dalam form student report. Pada detail student report admin dapat melihat hasil career test yang telah dilakukan oleh masing-masing siswa. Sehingga admin dapat memberikan saran dan rekomendasi mengenai jurusan apa yang cocok bagi para siswa sesuai dengan hasil career test yang telah dijalankan. Sedangkan pada menu application list, admin CV. XYZ dapat melihat informasi mengenai siswa dan siswi siapa sajakah yang telah melakukan pendaftaran ke universitas tujuan siswa dan siswi. Selain itu, admin juga dapat melakukan download dokumen syarat pendaftaran siswa yang telah di upload pada form pendaftaran.

\section{Kesimpulan dan Saran}

Berdasarkan pelaksanaan penelitian ini, dapat ditarik kesimpulan yaitu sebagai berikut.

1. Sistem yang dibangun mampu menampilkan informasi mengenai profiling kampus yang bekerja sama dengan CV. XYZ. Dengan adanya informasi ini diharapkan bahwa siswa dapat terbantu untuk mendapatkan informasi mengenai profil, persyaratan, dan lokasi kampus yang ingin dituju, sehingga proses pengurusan dokumen prasyarat akan lebih cepat dilakukan oleh para siswa

2. Sistem yang dibangun mampu mempermudah siswa dalam melakukan proses Career Test secara online. Dengan adanya ujian secara online maka hasil dari Career Test akan dengan cepat dapat diketahui sehingga efisiensi waktu siswa dalam menentukan jurusan dan kampus yang diinginkan akan lebih cepat sehingga proses pengambilan keputusan siswa dalam menentukan jurusan dan kampus akan lebih cepat terealisasi dan siswa pun tidak terhambat untuk segera melanjutkan studynya di luar negeri.

3. Sistem yang dibangun memudahkan Admin CV. XYZ dalam melakukan pengumpulan data siswa, dengan adanya sistem pendaftaran secara online proses penyimpanan berkas siswa akan menjadi lebih efisien karena data disimpan kedalam database.

Saran yang diberikan oleh peneliti, untuk pengembangan sistem selanjutnya adalah sebagai berikut.

1. Sistem Informasi Pendaftaran \& Career Test yang dibangun dapat dikembangkan dengan menambahkan fitur konsultasi online.

Sehingga dengan adanya fitur konsultasi online, siswa dapat menentukan jadwal konsultasi, dan melakukan konsultasi dengan admin CV. XYZ tanpa perlu datang langsung ke kantor.

Pengembangan di fitur penerjemahan dokumen, dengan translator dokumen secara online sehingga mempercepat proses pendaftaran ke Universitas di luar negeri. 


\section{Daftar Pustaka}

[1] Hutahaean, J., 2014, Konsep Sistem Informasi, $1^{\text {st }}$ ed, Deepublish Publisher, Yogyakarta.

[2] Kendal, K. E. \& K. J. E., 2013, System Analysis and Design, 9 ed, Prentice Hall, United States.

[3] Anhar, 2010, Panduan Menguasai PHP \& MySQL Secara Otodidak, $1^{\text {st }}$ ed, PT TransMedia, Jakarta Selatan. 